\title{
Reversing the Trend from "Early" to "Late" Exit: Push, Pull and Jump Revisited in a Danish Context
}

\author{
Per H. Jensen \\ Center for Comparative Welfare Studies, Aalborg Univesity, Fibigerstrade 1, Aalborg 9220, Denmark. \\ E-mail: perh@socsci.aau.dk
}

Denmark is a low exit country in EU-25. As such, the Danish experience contradicts most wisdom in mainstream research on the causes of early exit/retirement. The Danish labour market is one of the most brutal vis-à-vis older workers in Europe, while the Danish early retirement schemes are among the most generous in Europe. For these reasons one should expect Denmark to be a high exit country. The contrary is true. With this background, it is argued that cultural and social-psychological factors play a far stronger role in shaping retirement patterns than we tend normally to assume. Accordingly, in recent years Denmark has employed cultural steering based on the voluntary participation of firms and other social partners in attempts to raise further the employment rate of older workers. Cultural steering has been supplemented by the introduction of "positive" incentives, that is, individuals and municipalities are rewarded economically if retirement is postponed.

The Geneva Papers (2005) 30, 656-673. doi:10.1057/palgrave.gpp.2510046

Keywords: early exit; early retirement; labour markets; welfare policies; values; work orientation

\section{Introduction}

In the face of ageing populations, the Western countries are facing a major challenge to increase job opportunities and retain older workers in the labour market; however, it appears that some countries are more proficient than others at promoting the retention of ageing workers. While the workforces in EU Member States are generally shrinking, the employment rate of senior workers remains relatively high in countries such as Denmark. The employment rate in 2002 for those aged 55-64 years was 57.9 per cent, as compared to 38.7 per cent in EU-25. ${ }^{1}$ The high employment rate would seem to indicate that something is being done right in Denmark. As such, Denmark may potentially function as a place for policy learning in relation to EU policy considerations on how to promote "active ageing". In effect, this article examines the labour market situation of older workers in Denmark. The major question posed is: Why is the employment rate of older Danes so high?

${ }^{1}$ COM (2004); Nordheim (2004). 
To account for why or why not older workers exit the labour market, this article employs three models that are generally drawn upon to account for retirement from the workforce, that is, Push, Pull and Jump: ${ }^{2}$

- Push explanations emphasize that early retirees have been victimized by the social structures of industrial societies, that is, early retirement is first and foremost an outcome of exclusionary labour markets. ${ }^{3}$

- Pull explanations argue that generous social security provisions offer a strong economic incentive for early retirement, thus encouraging older workers to leave the labour market. ${ }^{4}$

- Jump explanations contend that older workers leave the labour market due to an irresistible impulse or desire to pursue a new course in life in search of new forms of self-fulfilment and self-actualization. ${ }^{5}$

Analytically, Push, Pull and Jump offer three distinct and separate explanations as to why early exit/retirement occurs. In practice, however, it can be quite difficult to draw clear distinctions between them, as they represent three interacting factors, ${ }^{6}$ that is, Push, Pull and Jump are not mutually exclusive explanations. Furthermore, it has also been argued that labour markets, welfare policies and the disposition of the individual are embedded in national early-exit cultures. ${ }^{7}$ Thus, Push, Pull and Jump have no independent meaning or life of their own; rather, Push, Pull and Jump are constructed differently in various early-exit cultures. On this background, the article at hand does not apply these models in the traditional sense, that is, as theories of (single) causal relationships. Instead, the article applies the Push, Pull and Jump models as an analytical framework, which may help to structure empirical observations as to why the employment frequency of older workers is relatively high in Denmark.

Despite its relatively favourable position, Denmark, like other EU countries, has sought to reverse the trend from "early exit" to "late"/"flexible exit". This turn took place in the late 1990s, when new policy measures were introduced that were aimed at combating the mechanisms of early retirement. It remains premature to give an account of the effects of these new measures. Nonetheless, this article provides a review of the initiatives introduced in Denmark over the past 5-8 years in order to facilitate the retention of older workers.

\section{Push factors}

Push explanations are related to structural change, work conditions, and individual employee characteristics. The axiom of the Push model is that if people could choose, they would prefer to work rather than leave the labour market. Push-conditioned exit

\footnotetext{
2 Jensen and Kjeldgaard (2002); Shultz et al. (1998); Snartland and Øverbye (2003).

${ }^{3}$ Knuth and Kalina (2002).

${ }^{4}$ Gruber and Wise (1999).

${ }^{5}$ Featherstone and Hepworth (1995).

${ }^{6}$ Kohli and Rein (1991).

${ }^{7}$ Guillemard (2003).
} 
is therefore essentially considered to be involuntary and undesired by the affected wage earners. From a Push perspective, early exit may be interpreted as exclusion from the labour market associated with a loss of welfare, that is, a loss in income, status, self-respect etc. Push explanations include three dimensions:

- at the individual level, Push occurs because of poor health, which may be caused by a poor physical and mental working environment;

- at the firm or company level, Push occurs as a result of layoffs and firings targeting older workers; and

- at the labour market level, Push occurs because older workers, once they have become unemployed, are unable to regain employment.

The level of unemployment functions as an overall framework for Push-conditioned exit from the labour market. ${ }^{8}$ For instance, the level of unemployment conditions the degree to which it is possible to rejuvenate the workforce, that is, replace older wage earners with new and younger segments in the labour market. From this perspective, unemployment has declined dramatically in Denmark since the mid-1990s. Between 1994 and 2002, overall unemployment decreased from 12.3 to 5.2 per cent, while the unemployment rate for people aged 50-66 years fell from 14.0 to 6.0 per cent. ${ }^{9}$ Unemployment for older workers remains higher than for other age groups; nevertheless, the considerable fall in unemployment for older workers marks a shift in employment opportunities. Between 1998 and 2002, labour force participation rates increased from 81.2 to 85.6 for people aged $50-54$ years, from 70.8 to 78.2 for people aged $55-59$ years, and from 29.4 to 30.0 for people aged $60-66$ years. ${ }^{10}$

\section{Push at the individual level}

Many studies have indicated that health conditions are a particularly decisive retirement factor. Poor health is especially decisive for those who exit the earliest. Health-motivated retirement has typically been analysed in relation to work environment problems. Thus, a recent Danish study reveals that those who have endured hard physical labour are particularly prone to early exit due to poor health conditions. ${ }^{11}$ In general, early exit/retirement in Denmark predominates among bluecollar workers and in goods-producing industrial sectors. ${ }^{12}$

Unskilled and less-educated workers are particularly exposed to early exit/ retirement. In 2002, the employment rate for people aged 55-59 years was 58 per cent for those with an elementary school education, and 91 per cent for those who had acquired a higher education. ${ }^{13}$ The link between labour force participation and

\footnotetext{
${ }^{8}$ Taylor and Walker (1994: p. 579 cont.).

${ }^{9}$ Danmarks Statistik (2003).

${ }^{10}$ Danmarks Statistik (1998 and 2004a).

${ }^{11}$ Jensen and Kjeldgaard (2002). This may change in the future, partly because the physical work environment is improving, and partly because lifestyle factors increasingly replace work environment as a source of poor health conditions.

${ }^{12}$ AK-Samvirke (2004).

${ }^{13}$ Nielsen (2004).
} 
Table 1 Educational level and retirement (1999)

\begin{tabular}{lccccc}
\hline & $\begin{array}{c}\text { Less than 10 } \\
\text { years education } \\
(\%)\end{array}$ & $\begin{array}{c}11-14 \text { years } \\
\text { education } \\
(\%)\end{array}$ & $\begin{array}{c}15-16 \text { years } \\
\text { education } \\
(\%)\end{array}$ & $\begin{array}{c}\text { More than 17 } \\
\text { years education } \\
(\%)\end{array}$ & $\begin{array}{c}\text { Total } \\
(\%)\end{array}$ \\
\hline Employed, 54-66 years of age & 29.5 & 50.2 & 12.4 & 7.9 & 100.0 \\
Early retired, 60-66 years of age & 40.4 & 50.8 & 8.1 & 0.8 & 100.0 \\
Disability pensioners & 47.8 & 44.9 & 5.5 & 1.8 & 100.0 \\
Total & 40.9 & 49.0 & 8.0 & 2.1 & 100.0 \\
\hline
\end{tabular}

Source: Own data. In this article, "own data" refers to survey data collected in 1999. The survey was designed by Jørgen Goul Andersen and Per H. Jensen, Centre for Comparative Welfare Studies, Aalborg University. The survey was conducted as telephone interviews carried out by Statistics Denmark. The data set describes a representative sample of three subsections of the population, that is (a) fully employed,

(b) unemployed and (c) early retired. For a full description of the survey, response rates etc., see Clement et al. (2002).

educational attainment is not clear-cut, however, as less-educated workers suffer disproportionately from poor health conditions.

As seen in Table 1, there is a relationship between educational attainment and health, as low levels of education affect early retirement, particularly in terms of the disability pathway. Only 29.5 per cent of older workers in employment have less than 10 years education as compared to 47.8 per cent of all disability pensioners. Still, the granting of disability pension is not solely dependent on health conditions. For instance, the level of unemployment has historically impacted the development of disability pensioners. Towards the end of the 1990s, economically vulnerable municipalities with high levels of unemployment found themselves with more persons on disability pension as compared with economically robust municipalities. ${ }^{14}$

\section{Push at the firm or company level}

Small- and medium-sized firms mark the occupational structure in Denmark. About 50 per cent of all jobs are in companies with less than 50 employees. ${ }^{15}$ In effect, lifelong employment relationships are rare in Denmark. Thus, labour markets are flexible and job mobility and personnel turnover is high. In 1994-1995, for instance, 775,000 persons in the total labour force of 2.9 million were unemployed for shorter or longer periods. Most, however, suffered only short-term unemployment, as more than 50 per cent of these 775,000 persons were unemployed for less than $15-16$ weeks. ${ }^{16}$

Relatively weak employment protection and fairly liberal hiring and firing practices frame labour market flexibility in Denmark. In practice, some segments of blue-collar workers in ordinary jobs can be discharged from 1 day to the next, or from $1 \mathrm{~h}$ to the next without advance notice. The risk of joblessness stemming from layoffs is high, and elderly workers have suffered disproportionately from the high degree of

\footnotetext{
${ }^{14}$ Den Sociale Ankestyrelse (1998).

15 Danmarks Statistik (2004a).

${ }^{16}$ Finansministeriet (1995).
} 
Table 2 Employment protection and layoff of older workers in a comparative perspective

\begin{tabular}{lcc}
\hline & $\begin{array}{c}\text { Procedural factors that restrict } \\
\text { employer's ability to dismiss } \\
\text { workers (at the end of the 1990s): } \\
\text { overall score }\end{array}$ & $\begin{array}{c}\text { Percentage of retired men (aged 55-64 } \\
\text { years), whose main reason for leaving last } \\
\text { job or the labour was dismissal or } \\
\text { redundancy }\end{array}$ \\
\hline Denmark & 0.5 & 23.4 \\
France & 2.8 & 10.7 \\
Germany & 3.5 & 9.5 \\
Italy & 1.5 & 2 \\
The Netherlands & 5 & 7.9 \\
Spain & 2 & 10.2 \\
United Kingdom & 1 & 22 \\
\hline
\end{tabular}

Source: OECD (1999); The European Union Labour Force Survey (1995).

Note: The overall score can lie between 0 and 6 . The highest values denote the most extensive employment protection. For a review of the way in which the "overall score" is estimated, see OECD (1999 Annex 2.B).

personnel turnover. As can be seen in Table 2, low levels of employment protection and flexible labour markets have fuelled the trend toward early exit/retirement in Denmark. ${ }^{17}$

Several reasons may explain why older workers in Denmark are unattractive labourers and must therefore leave a job on account of layoffs and firings. Thus, older workers may be less productive than younger workers. If this is the case, the earnings of older workers will be an important determinant of their employability. According to this perspective, Denmark exhibits high relative wages of older workers. ${ }^{18}$ Still, the relative wages of older workers in Denmark are, for instance, far lower than are the relative wages of older workers in Germany and Italy, that is, in countries where older workers are less exposed to dismissal or redundancy as compared to Denmark.

Furthermore, the willingness and ability of older workers to acquire new skills may determine their employment prospects. From this perspective, some studies indicate that older workers in Denmark are enrolled in training or re-training to a lesser degree than younger workers. ${ }^{19}$ In part, this may be explained by discrimination in as much as older workers are not offered training as often as others. In part, older workers themselves may not feel a need to learn new skills. They are therefore reluctant to participate in re-training. This may be the case if older workers have jobs with which they are highly familiar. In such cases, the problem appears if a job disappears, and the older worker cannot be transferred to another job due to lack of skills.

Whatever the case, it is safe to say that only a minority of older workers have been subject to senior policy instruments in order to counteract Push at the level of the firm or company. In 1999 only 23.3 per cent of all beneficiaries of early retirement benefits

\footnotetext{
${ }^{17}$ Thus, a low level of employment protection in Denmark has a different meaning and a different effect as compared to Switzerland, where loose employment protection has contributed to a high employment rate among older workers (cf. Dorn and Sousa-Poza (2003)).

${ }^{18}$ OECD (1998).

${ }^{19}$ Jørgensen (1997).
} 
could respond in the affirmative to the following question: "Did a discussion take place with management regarding continued association with the firm prior to the transition to early retirement?" (own data). Nevertheless, a study conducted in the late 1990s reveals that 85 per cent of the public sector and 60 per cent of private firms with more than 10 employees had an active senior policy. ${ }^{20}$ Without a doubt, however, these figures exaggerate the actual prevalence of senior policies. The existence of a formal policy does not therefore guarantee that the firm acts in a senior-friendly manner. Evidence points to good practices being implemented particularly in knowledge-intensive firms and companies. ${ }^{21}$

\section{Push at the level of the labour market}

Once older workers become unemployed, their chances of gaining new employment are relatively slim. Owing to negative age stereotypes and discriminatory practices, older job seekers are disadvantaged when competing for jobs. ${ }^{22}$ Age has become an independent criterion when recruiting staff, which discourages older workers from job search activities. In effect, older unemployed persons often resign and choose to retire.

It must also be acknowledged, however, that older workers are considered to be less appealing when recruiting is taking place, as they are generally the least educated and qualified segment of the labour force. According to local labour market authorities in Denmark, inadequate qualifications constituted a major barrier to bringing unemployed persons over the age of 50 years back into employment in the late 1990s. ${ }^{23}$ As elderly workers are generally the least qualified segment of the labour force, the OECD has noted that "well-targeted labour market policies (ALMPs) could help address the specific labour market problems of older age workers". 24 As Denmark invested roughly 1.95 per cent of GPD in active labour market policies in $1996,{ }^{25}$ it is quite notable that older people have not had access to these active labour market programmes. Prior to 1996, the 50-59 year olds were not included in the rights and obligations for activation, that is, they were excluded from offers of job training, education, etc., and it was not until 2000 that those over 60 years of age were formally included in the activation measures. Nonetheless, local labour market authorities can determine the guidelines for whether and when obligations for activation can be ignored for those 58- and 59-year-old unemployed persons who are entitled to unemployment insurance. Conversely, the rules for activation are more restrictive for unemployed persons over 60 years of age than for unemployed persons between 30 and 59 years. A right and obligation therefore exists to activate persons over 60 years of age already after 6 months of unemployment, while unemployed persons between 30 and 59 years are first to be activated after 1 year.

\footnotetext{
${ }^{20}$ Ibid.

${ }^{21}$ Hansen (2002); Jensen (2004a).

22 OECD (1998); Taylor and Walker (1994 and 2003).

${ }^{23}$ Højgaard and Klith (1997: 38).

${ }^{24}$ OECD (1996: 78).

${ }^{25}$ OECD (1999).
} 
Table 3 Question: “Are you willing to accept a job with poorer wage and work conditions as compared to your qualifications and experience, if this could help you to regain employment?"

\begin{tabular}{lcccc}
\hline & Yes (\%) & $\begin{array}{c}\text { Yes, but only if it was forced } \\
\text { upon me by the employment } \\
\text { service or local authority }(\%)\end{array}$ & No (\%) & Total (\%) \\
\hline 18-24 years of age & 36.0 & 16.0 & 48.0 & 100.0 \\
25-29 years of age & 34.5 & 27.6 & 37.9 & 100.0 \\
30-39 years of age & 38.2 & 21.3 & 40.4 & 100.0 \\
40-49 years of age & 44.3 & 12.9 & 42.9 & 100.0 \\
$50-59$ years of age & 45.5 & 18.2 & 35.4 & 100.0 \\
Total & 41.6 & 18.6 & 39.8 & 100.0 \\
\hline
\end{tabular}

Source: Own data.

As already mentioned, unemployment - and long-term unemployment in particular - may discourage older workers from seeking employment. Nonetheless, some segments of unemployed seniors display a very strong desire to regain employment.

As can be seen in Table 3, older unemployed persons are much more desperate than younger unemployed persons to regain employment. The older unemployed are therefore willing to adapt to lower wage rates and working conditions if this could get them back to work.

\section{Recent changes}

The mid-1990s marked a turning point with regard to the social acceptance of Pushconditioned exit from the labour market. Productive ageing was formally initiated in 1994, when the Ministry of Social Affairs initiated a campaign for an all-inclusive labour market with the aim of integrating welfare recipients and disability pensioners into paid employment. The Ministry of Labour initiated a similar campaign in 1996, when the National Labour Market Board discussed how to strengthen the employment opportunities for elderly beneficiaries of unemployment benefits. However, various social actors such as government agencies, ageing workers, employers, trade unions etc. have been involved in combating the Push mechanisms and thus extending the working life of older workers. The measures taken by the social partners are an integrated strategy, without it being coordinated in a premeditated way. ${ }^{26}$ Nevertheless, as of the mid-1990s, cultural steering became the preferred method in attempts to provide opportunities for a more productive old age.

Cultural steering is about inducing new ideals about the correct relationship between ageing and work. Thus, new ideals about active ageing have been added to the popular discourse by means of information and persuasion campaigns, conferences, the distribution of information about good practices, etc. propagating the advantages of retaining and recruiting older workers. Still, cultural steering is not merely about

\footnotetext{
${ }^{26}$ Hansen (2002).
} 
putting the "ageing issue" on the agenda; cultural steering is also about making it "trendy" to employ "senior-friendly" recruitment practices. To some extent, the new discourses have been institutionalized as new schemes of perceptions generating new practices at the micro-level, in the companies, and at the macro-level vis-à-vis older workers. In order to become more efficient, however, cultural steering has been backed by welfare state encouragement and negotiations among social partners.

The training of older unemployed people is probably the most obvious means of combating Push at the labour market level. Following this line of argument, the exclusion of older workers from the active labour market programs was - formally and symbolically - abandoned as of 1996. Furthermore, active labour market policies have been supplemented since 1998 by other measures aiming at counteracting Push in the labour market. First, projects aimed at providing jobs for unemployed seniors are subsidized economically. Second, in accordance with the help-to-self-help principle, the so-called self-activation groups consisting of $50+$-year-old job seekers are supported financially. The aim of the self-activation groups is to support and motivate unemployed seniors in their search for work. In January 2003, 24 self-activation groups with a total of 1,823 members were established. About 50 per cent of the members found work. ${ }^{27}$

In Denmark, the introduction of anti-age discrimination legislation aimed at countering Push at the company level has not been an option. All social partners in Denmark are sceptical about anti-discrimination legislation as a means of transforming employer practices and attitudes. Even the Danish Council of Organisations of Disabled People disassociated itself from the introduction of a stricter employment protection of older and/or disabled persons. Still, a very soft measure has been introduced in order to counteract Push at the company level. A free consultancy of $5 \mathrm{~h}$ is offered to firms to help them in the formulation of "senior-friendly" personnel policies.

In an effort to combat Push at the individual level, flexible exit opportunities in the form of part-time work have been introduced in collective agreements since the late 1990s. No doubt, however, public sector employers are forerunners vis-à-vis private sector employers in the implementation of flexible retirement opportunities. In the private sector, the flexible retirement opportunities are most prevalent in the service sector. ${ }^{28}$ Nevertheless, subsequent to collective bargaining negotiations in 1995, most labour agreements now include "social clauses" allowing for the local creation of new types of jobs in terms of wages and working conditions for people with reduced working capacity. The "social clauses" include older workers as one of several target groups, others being disabled people.

\section{Pull factors}

Pull explanations interpret early exit/retirement as an effect of incentives and symbolic signals of pension and early retirement schemes. Pull explanations rest on the tacit

\footnotetext{
${ }^{27}$ Discus (2003).

${ }^{28}$ For example Beskæftigelsesministeriet (2003).
} 
assumption that retirement is mainly voluntary, a result of the free will of the individual. There are two sub-types of such explanations:

- Explanations rooted in economic theory assume that the decision to retire depends on the financial incentives that are built into the early retirement schemes. ${ }^{29}$ Thus, generous early retirement schemes cause people to find it more advantageous to allow themselves to accept early retirement than to work.

- In sociologically oriented theories,${ }^{30}$ individuals are assumed to react to the signals of retirement programmes (for example the pension age), which are regarded as an institutional expression of societal values, norms and conventions. Such schemes reproduce our culturally constructed notions of when it is appropriate to leave the labour market.

Whatever the case, the existence of public or private retirement schemes contributes to define a "desirable" relation between ageing and work and is therefore of importance for the timing of retirement. In effect, the early retirement rules in most European countries have been tightened, rendering it less attractive to leave the labour market in an attempt to reverse the trend towards early retirement. ${ }^{31}$ Such changes in incentives, however, may pose a threat to the living standards of older workers and their families. ${ }^{32}$

As has been the case in most other European countries, pension and early retirement schemes in Denmark have been thoroughly reformed since the late 1990s. In Denmark, however, a different path for development has been pursued than in most other European countries. In an attempt to change "early" exit to "late" exit, Denmark has chosen to institute "positive" incentives, that is, individuals and municipalities are rewarded economically if retirement is postponed.

\section{Pathways out of working life}

In Denmark, there are four major personal routes out of working life, that is, public old-age pension, unemployment benefits, early retirement benefits, and disability benefits. All four schemes have been thoroughly reformed since the late 1990s.

Anyone having resided in Denmark for more than 40 years is eligible for old-age pension. The pension is composed of a flat-rate benefit and an income-tested supplementary benefit. In 2003, the flat-rate benefit amounted to approximately EURO 7,200 annually. Historically, the age criterion for eligibility has been relatively high. In 1999, however, Parliament lowered the age of entitlement from 67 to 65 years as of $2004 .{ }^{33}$ For some technical reason, lowering the age of entitlement led to a reduction in public expenditures in conjunction with a major reform of the early retirement scheme. Furthermore, entitlement to old age pension does not mean that one must accept retirement at that age; rather, the contrary is true. In order to encourage older workers to remain in the labour market after the age of 65 years, the

\footnotetext{
${ }^{29}$ Gruber and Wise (1999).

${ }^{30}$ Atchley (1982).

31 Reday-Mulvey (2005).

32 OECD (1998).

33 Jensen (2004b).
} 
deduction in the flat-rate pension benefit due to other sources of income was reduced from 60 to 30 per cent. Furthermore, the threshold for deductions in old age pension was increased. In 2003, no deductions were made if other sources of income did not exceed roughly EURO 30,000.

Unemployment benefits are a relatively attractive pathway out of the labour market. Once entitled to unemployment benefits, a jobless worker receives 90 per cent of his previous wage, though up to a ceiling which in January 2004 was about EURO 85 per day or approximately EURO 425 per week. The duration of unemployment benefits throughout the 1990s has been successively reduced from nine to four years in 1999; however, special regulations have ensured that no recipient of unemployment benefits over the age of 50 years would lose their right to unemployment benefits. In 1999, this protection was eliminated for those aged 50-54 years, whereas special arrangements were retained for the 55-59-year-old age group. A member of an unemployment insurance fund who has reached 55 years of age, and who via continued membership and payment would otherwise have been able to fulfil the eligibility criteria for early retirement at the age of 60 years, retains the right to unemployment benefits until the age of 60 . A member of an unemployment fund who has reached the age of 60 can receive unemployment benefits for a maximum of 2.5 years. ${ }^{34}$ The abbreviated period with unemployment insurance for those over 60 years of age and the early activation measures are intended to prevent those over age 60 years who are unavailable for the labour market to find it more economically advantageous to remain a recipient of unemployment benefits rather than to be transferred to early retirement benefits.

The early retirement scheme for older workers aged 60-65 years was introduced in 1979. By July 1999, however, the early retirement scheme was subject to major reform. $^{35}$ The aim of this reform was to motivate more people in their early 60 s to remain in the labour market:

- The eligibility criterion was changed in such a way that the mandatory minimum of 20 years' membership in an unemployment insurance fund was raised to 25 years within the last 30 years.

- The transition from work to retirement was made more flexible by repealing most restrictions regarding the amount an early retiree is allowed to work.

- The retirement benefits structure was changed. Previously, the benefit would be scaled down from 100 to 82 per cent of unemployment benefits over a number of years. In the new system, the early retiree would receive 91 per cent of unemployment benefits during the entire period of early retirement.

- It was made economically advantageous to postpone early retirement. (i) The early retiree will generally receive 91 per cent of unemployment benefits, but if retirement is postponed to age 62 years, the level of early retirement benefit rises to 100 per cent of unemployment benefits. (ii) An individual who postpones early retirement until age 62 will be entitled to a tax exemption of approximately EURO 1,100 for each segment of 481 hours worked between the ages of 62 and 65 years. In other words,

\footnotetext{
${ }^{34}$ Beskæftigelsesministeriet (2003).

35 Jensen (2004b).
} 
those who do not utilize their right to early retirement at all will receive a tax exemption of roughly EURO 13,700 upon reaching age 65 years. With contributions and benefits taken into account, it has been calculated that the tax exemption award will yield a net gain of EURO 6,000 for those postponing retirement until age 65 years. (iii) For early retirees (age 60-62 years) with additional income from individual pension savings, etc., 60 per cent of their additional income will be deducted from the early retirement benefit; however, individuals choosing to postpone exit from the labour market (between the ages of 62 and 65), will only have certain types of personal income deducted from their retirement benefits.

The early retirement scheme implemented in 1999 offers considerable financial incentives to older workers to postpone early retirement. When the reform was introduced, the government expected that the new scheme would increase labour force participation by $4-5$ per cent among those aged $60-64$ years until $2009 .{ }^{36}$

The origin of the disability scheme can be traced back to the early 1920s. ${ }^{37}$ This scheme is financed by general taxation and administrated by the municipalities, that is the municipalities are responsible for awarding disability pension. All age groups between 18 and 65 years are eligible for disability pension if employability is reduced because of illness, impairment etc. A fundamental precondition for granting disability pension, however, is that all efforts intended to improve the employability of the individual by means of medical treatment, education, etc, have proven futile. Still, until recently, people above 50 years of age could be granted disability pension for non-medical reasons, for example, if the person in question had no prospects in the labour market. In principle, this is no longer the case, as reforms in 1999 and 2003 thoroughly reformed the disability pension scheme:

- The benefit structure was simplified in 2003. Prior to this reform, disability benefits were subdivided into four different categories, and the benefit granted was dependent on the degree of disability. As of 2003, the disability benefit has been unified, and the disability benefit for single disability pensioners equals the unemployment benefit.

- In the 1980s, the Danish state fully reimbursed the municipalities for their disability pension expenditures. Over the years, however, the state's reimbursements have been reduced. Since 1999, the state only refunds 35 per cent of the expenditures of the local authorities on newly granted disability pensions. Consequently, the municipalities must finance most of the costs of disability pensions with local taxes. Danish municipalities previously had a financial incentive to unload persons with "employment issues" on the state by granting them state-financed disability pensions. As such, this reduction in state subsidy functions as an incentive for local authorities to be thorough when granting disability pensions.

- New measures are aimed at reducing labour market exclusion. A new approach has been employed in processing applications. The old criterion, that is, "loss of employability", has been replaced by "working capacity" in approaching the

\footnotetext{
${ }^{36}$ Det Seniorpolitiske Initiativudvalg (1999).

${ }^{37}$ Jensen (2003).
} 
problems of disabled persons. By focusing on working capacity, it is expected that attention will be directed towards the resources and development potential of disabled individuals rather than their problems and limitations. In principle, a fundamental precondition for granting disability pension is that every effort to improve the employability of the individual by means of activation, medical treatment, etc., has proven futile. Thus, to the extent possible, any person meeting the criteria for a disability pension is offered a full-time "flex job", where wages and working conditions are similar to existing agreements within the given industry. Another measure, that is, part-time "soft jobs", is reserved for those already receiving disability pensions. The earned income from a soft-job is supplemented with disability pension. Wages and working conditions in soft jobs are agreed upon between employer and employee in collaboration with the relevant union. The municipality subsidizes flex and soft jobs. As of January 2003, 19,961 flex jobs and 4,941 soft jobs had been created. ${ }^{38}$

Overall, the aim of the disability reforms has been to ensure that people who have not entirely lost their employability remain in the labour market rather than end up as passive clients of the welfare system.

\section{Did generosity kill the cat?}

From a comparative perspective, the Danish early exit/retirement schemes are rather generous in terms of eligibility criteria and benefit levels. ${ }^{39}$ Net replacement rates in particular are high for low-income workers. From a Pull perspective, this might lead one to expect the development of an early exit culture in Denmark; rather, the contrary is the case. The employment rate of older workers in Denmark is among the highest in Europe. This contradiction may be explained by the existence of a very strong work orientation in Danish culture.

As Table 4 shows, Danes are probably less inclined to leave the labour market as compared to populations in other European countries. Table 4 may be biased, however, since the ISSP data includes all age groups. Nevertheless, there is evidence indicating that non-pecuniary concerns dominate the labour force decisions of older $\left(65+\right.$ years) people. ${ }^{40}$ Whatever the case, older workers in Denmark remain in the labour market far more than is the case with older workers in other European countries. In other words, the Danish case demonstrates that generous early retirement benefits are compatible with high levels of labour force participation.

\section{Jump factors}

Jump is regarded as a voluntary phenomenon, ${ }^{41}$ where the decision to retire is not determined by economic incentives, norms or conventions. Rather, and in accordance

\footnotetext{
${ }^{38}$ Danmarks Statistik (2004b).

${ }^{39}$ Hansen (2002); SZW (1997); Taylor et al. (2000).

${ }^{40}$ Haider and Loughran (2001).

${ }^{41}$ Jensen and Kjeldgaard (2002).
} 
The Geneva Papers on Risk and Insurance - Issues and Practice

668

Table 4 Attitudes to work in a comparative perspective

Percent of population who "agree entirely" or "agree" with the following statement: I would like to have a job, even though I don't need the money

$\begin{array}{ll}\text { Denmark } & 76.9 \\ \text { France } & 52.7 \\ \text { Germany } & 71.3 \\ \text { Italy } & 51.7 \\ \text { The Netherlands } & 51.7 \\ \text { Spain } & 49.7 \\ \text { England } & 55.0\end{array}$

Source: ISSP, 1997.

with current theories of value change, ${ }^{42}$ retirement is guided by inner motivations, irresistible impulses, or a desire to realize individual potential in an active third age. If such motives are dominant, welfare arrangements will only have secondary importance for decisions concerning retirement. A possible drop in material comfort will thus be compensated by improved quality of life. Jump explanations distinguish between two types of gains associated with early retirement, that is, "experience" or "social gains".

Experience gains refer to the idea that the individual can strive to (re-)build his or her life project, for example, a new education, world travel etc., and generally pursue challenges which, at the personal level, are felt to be more beneficial and more important than work (spiritual and artistic pursuits, physical hobbies, etc.). There is some indication that a segment of the early retirees have chosen to retire in order to acquire free time to cultivate or maintain already established leisure pursuits.

As revealed in Table 5, 23 per cent of all retirees report that they have sought out new experience gains; however, this does not provide a basis upon which to deduce that all those responding in the affirmative to the question have exited the labour market exclusively to harvest experiential gains.

Social gains refer to the retiree devoting him/herself to activities in local communities, circles of friends, and the family. Family conditions are an often-cited reason for the justification of retirement. A retired spouse in particular represents a major Jump factor. ${ }^{43}$ Studies thus indicate that the female partner is inclined to follow her husband out of the labour market in those instances where the male is the oldest. ${ }^{44}$ (The male is older than the female in the majority of marital relationships.) One can thereby substantiate that, on average, men in Denmark withdraw from the labour market 2 years later than is the case with women, and that the employment frequency of 60-66-year-old men is roughly twice that of women in the same age group. ${ }^{45}$ Other

\footnotetext{
42 Inglehart (1997).

43 Coile (2003).

44 SOU (2004).

${ }^{45}$ Nielsen (2004).
} 
Table 5 Question to retirees: "Subsequent to retirement, have you started a project you have always dreamed of doing?"

\begin{tabular}{lccc}
\hline & Yes $(\%)$ & No $(\%)$ & Total $(\%)$ \\
\hline Males & 22.2 & 77.8 & 100.0 \\
Females & 23.7 & 76.3 & 100.0 \\
Total (\%) & 23.0 & 77.0 & 100.0 \\
\hline
\end{tabular}

Source: Own data.

Table 6 Questions to retirees: "Were you motivated to leave the labour market by the fact that it gave you the opportunity to help your children or grandchildren?"

\begin{tabular}{lccc}
\hline & $\begin{array}{c}\text { "Very much" or "A } \\
\text { little" (\%) }\end{array}$ & $\begin{array}{c}\text { Not very much" or } \\
\text { "Not at all" (\%) }\end{array}$ & Total $(\%)$ \\
\hline Males & 20.5 & 78.5 & 100.0 \\
Females & 27.4 & 72.6 & 100.0 \\
Total (\%) & 24.2 & 75.8 & 100.0 \\
\hline
\end{tabular}

Source: Own data.

aspects of family relationship that can motivate seniors to Jump are care for older family members or spending more time together with children or grandchildren.

As can be seen in Table 6, women are more disposed to cease working in order to be together with and/or care for their children or grandchildren than is the case with men. More generally, there is a tendency for more women than men to Jump for family reasons.

\section{Recent changes}

It is currently being debated in Denmark whether it is reasonable that early retirement schemes are paying for employable seniors to be able to leave the labour market to play golf, collect stamps or spend time together with their grandchildren, etc. Another matter of current debate is whether or not the age of retirement ought to be raised in order to reinforce labour market activity. This debate is setting the scene for reforms regarding the age of retirement and the early retirement scheme subsequent to the next elections. The question remains, however, as to whether this will have significant effects on retirement patterns.

There is an inclination to overlook the fact that the Danish pension systems have been privatized. While the Danish pension system is indeed a four-pillar-system, ${ }^{46}$ in the future, the private collective bargaining-based occupational pension system will come to serve as the dominant form of pension payments. Pension payments will therefore build on strict actuarial principles. The size of the individual's total pension

${ }^{46}$ Pedersen (2004). 
will therefore strongly depend on when they retire, which, from a Pull perspective, will serve as a strong incentive to postpone retirement. From a Jump perspective, however, one ought to expect the opposite effect: those prone to Jump make sure that they have sufficient means to live an active "third age", and the occupational pension system will help them reach that level at an earlier stage than possible at present. Indeed, a recent Danish study suggests that this might actually be the case. ${ }^{47}$

\section{Conclusion}

One of the greatest challenges facing the contemporary welfare states is that older wage earners are leaving the labour market before reaching retirement age. From a comparative perspective, however, the Danish situation is rather favourable. Drawing analytical distinctions between Push, Pull and Jump factors, the purpose of this article has been to describe the circumstances behind the relatively high employment rate among older workers in Denmark.

- From a Push perspective, the Danish labour market is rather brutal (no employment protection, high turn-over rates, etc.) and exclusionary vis-à-vis older workers. The employment frequency among older workers in Denmark is nevertheless greater than the employment frequency among seniors in pretty much all of the other $25 \mathrm{EU}$ countries. In other words, the Danish experience is an example of how an abnormally liberal and efficiently functioning labour market is compatible with high employment rates for older workers.

- From a Pull perspective, welfare policies exhibit relatively soft eligibility criteria and relatively generous benefits. Nevertheless, despite the fact that early retirement schemes are generous in Denmark, the employment frequency among Danish seniors is higher than the employment frequency in almost all of the other $25 \mathrm{EU}$ countries.

- As to Jump, one can ascertain that this is not a particularly widespread phenomenon at present, though it is more prevalent among women than among men. This is most likely due to a very strong work orientation in Denmark. 76.9 per cent of all Danes would be happy to work even if they did not need the money.

The Danish experience indicates that the causes and effects of early exit/retirement are highly complex. We cannot rule out a possible effect on retirement from the functioning of the labour market; it is also impossible to rule out a possible effect of welfare policies. However, there is probably no reason to doubt that cultural and socio-psychological factors play a far stronger role in shaping retirement patterns than we normally tend to assume. In Denmark, at least, there is a clear correlation between a strong preference for work and a high employment rate among older workers.

In many European welfare states, the primary means for reversing the trend toward early exit/retirement has been reducing the social entitlements to early retirement. However, cutting such benefits effectively punishes those who have not had a free choice regarding retirement, that is, those who have been pushed out of the labour

${ }^{47}$ Leeson (2004). 
market. As such, Denmark has chosen a different route in attempts to increase the level of labour force participation among the older segment of the population:

- By means of cultural steering, campaigns have been aimed at fuelling a culture among employers, unions and younger workers, which acclaims the skills, experience and knowledge of older workers.

- Subsidising the formation and development of senior-friendly policies in private and public companies has helped to improve working conditions for older workers.

- Early exit/retirement schemes have become more flexible. Flexible retirement schemes better enable the affected individual to choose freely when and the extent to which he or she wishes to leave the labour market.

- New and flexible employment opportunities have been established (flex and soft jobs, social clauses etc.).

- The position of the individual worker has been strengthened by means of the inclusion of older workers into active labour market policies, help-to-self-help in job hunting, etc.

- 'Positive' incentives have been installed, providing economic rewards to individuals and institutions if early retirement is postponed.

The Danish experience does not represent the best of all worlds. Nonetheless, with due consideration to cultural differences, the Danish way of reversing the trend from "early" to "late" exit might serve as a source of inspiration in developing a socially sustainable means of handling the early retirement problem. From the point of view of the social sciences, however, the greatest challenge is to theorize and conceptualize the cultural differences and to clarify the cultural characteristics that support/counter the trend towards early exit/retirement.

\section{References}

AK-Samvirke (2004) Efterl $\varnothing n$ - myter og realiteter, København: AK-Samvirke.

Atchley, R.C. (1982) 'Retirement as a social institution', Annual Review of Sociology 8: 263-287.

Beskæftigelsesministeriet (2003) Rapport fra Udvalget vedr. Langere tid på arbejdsmarkedet, København: Finansministeriet.

Clement, S.L., Pedersen, J.J. and Sørensen, L.B. (2002) Teknisk rapport til undersøgelsen 'Arbejdsløshed, tilbagetrakning og medborgerskab, CCWS technical paper (2004-5), Centre for Comparative Welfare Studies, Aalborg.

Coile, C. (2003) Retirement incentives and couples' retirement decisions, working paper (WP 2003-04), Center for Retirement Research at Boston College, Chestnut Hill, MA.

COM (2004) Increasing the Employment of Older Workers and Delaying the Exit from the Labour Market, Brussels: Commission of the European Communities, p. 146.

Danmarks Statistik (1998) Statistisk årbog 1998, København: Danmarks Statistik.

Danmarks Statistik (2003) Statistisk tiårsoversigt 2003, København: Danmarks Statistik.

Danmarks Statistik (2004a) Statistisk årbog 2004, København: Danmarks Statistik.

Danmarks Statistik (2004b) Statistiske efterretninger - arbejdsmarked (2004: 23), København: Danmarks Statistik.

Den Sociale Ankestyrelse (1998) Førtidspensioner - Arsstatistik, København: Den Sociale Ankestyrelse.

Det Seniorpolitiske Initiativudvalg (1999) Seniorerne \& arbejdsmarkedet - nu og i fremtiden, København: Arbejdsministeriet.

Discus (2003) Evaluering - Arbejdsmarkedsstyrelsens Selvaktiveringspulje 2002, København: Arbejdsmarkedsstyrelsen. 
672

Dorn, D. and Sousa-Poza, A. (2003) 'Why is the employment rate of older swiss so high? an analysis of the social security system', The Geneva Papers on Risk and Insurance - Issues and Practice 28: 652-672.

Featherstone, M. and Hepworth, M. (1995) 'Images of positive ageing: A case study of retirement choice magazine', in M. Feathersone and A. Wernick (eds) Images of Ageing - Cultural Representations of Later Life, London and New York: Routledge.

Finansministeriet (1995) Finansredeg $\varnothing$ relse 95, København: Finansministeriet.

Gruber, J. and Wise, D.A. (1999) Social Security and Retirement Around the World, Chicago: University of Chicago Press.

Guillemard, A.-M. (2003) 'Concluding remarks. Company practices and public policies regarding age: Lessons drawn from comparisons', The Geneva Papers on Risk and Insurance - Issues and Practice 28: 673-676.

Haider, S. and Loughran, D. (2001) Elderly labor supply: Work or play?, working paper (WP 2001-04), Center for Retirement Research at Boston College, Chestnut Hill, MA.

Hansen, H. (2002) 'Active strategies for older workers in Denmark', in M. Jepsen, D. Foden and M. Hutsebaut (eds) Active Strategies for Older Workers, Brussels: ETUI.

Højgaard, J. and Klith, P. (1997) Aldre og arbejdsmarkedet, København: Ældre Sagen.

Inglehart, R. (1997) Modernization and Postmodernization: Cultural, Economic and Political Change in 43 Countries, Princeton, NJ: Princeton University Press.

Jensen, P.H. (2003) 'Disability pensions: Trends and policies in Denmark', in C. Prinz (ed) European Disability Pension Policies - 11 Country Trends 1970-2002, Aldershot: Ashgate, pp. 139-164.

Jensen, P.H. (2004a) 'Hvorfor er erhvervsdeltagelsen blandt ældre så høj i Danmark?', Social Kritik 94: 4-23.

Jensen, P.H. (2004b) 'Ageing and work: From "early" exit to "late" exit in Denmark', in T. Maltby, B. de Vroom, M.-L. Mirabile and E. Øverbye (eds) Ageing and the Transition to Retirement, Aldershot: Ashgate, pp. 41-66.

Jensen, P.H. and Kjeldgaard, T. (2002) 'Årsager og effekter af den tidlige tilbagetrækning fra arbejdsmarkedet', ARBEJDSliv 4(3): 43-62.

Jørgensen, K. (1997) Aldre og arbejdsliv - Tilbagetrakningsmønstre og seniorpolitik, København: Udviklingscenteret.

Knuth, M. and Kalina, T. (2002) 'Unemployment as a transition from employment to retirement in West Germany', European Societies 4: 393-418.

Kohli, M. and Rein, M. (1991) 'The changing balance of work and retirement', in M. Rein, M. Kohli, A.-M. Guillemard and H. Van Gunsteren (eds) Time for retirement - Comparative Studies of Early Exit from the Labor Force, Cambridge: Cambridge University Press.

Leeson, G.W. (2004) Arbejde og tilbagetrakning, København: Ældre Sagen.

Nielsen, T.M. (2004) De aldre og arbejdsmarkedet, København: Danmarks Statistik.

von Nordheim, F. (2004) 'Responding well to the challenge of an ageing and shrinking workforce. European Union policies in support of Member Stat efforts to Retain, Reinforce \& Re-integrate Older Workers in employment', Social Policy \& Society 3(2): 1-9.

OECD (1996) Ageing in OECD Countries, Paris: OECD.

OECD (1998) Employment Outlook, Paris: OECD.

OECD (1999) Employment Outlook, Paris: OECD.

Pedersen, A.W. (2004) 'The privatization of retirement income? Variation and trends in the income packages of old age pensioners', Journal of European Social Policy 14(1): 5-23.

Reday-Mulvey, G. (2005) Working Beyond 60 - Key Policies and Practices in Europe, Basingstoke, UK: Palgrave Macmillan.

Shultz, K.S., Morton, K.R. and Weckerle, J.R. (1998) 'The influence of push and pull factors on voluntary and involuntary early retirees retirement decision and adjustment', Journal of Vocational Behaviour 53: 45-57.

Snartland, V. and Øverbye, E. (2003) Skal jeg bli eller skal jeg gå? Pensjonsforventninger hos larere og ingeniører, rapport 21/03, NOVA, Oslo.

SOU (2004) Kan vi räkna med de äldre?, Stockholm: Statens Offentliga Utredningar.

SZW (1997) Income Benefits for Early Exit from the Labour Market in Eight European Countries - A Comparative Study, Den Haag: Ministerie van Sociale Zaken en Werkgelegenheid.

Taylor, P., Tillsley, C., Beausoleil, J. and Wilson, R. (2000) Factors affecting retirement, research report, Department for Education and Employment, Nottingham. 
Taylor, P. and Walker, A. (2003) 'Age discrimination in the labour market and policy responses: The situation in the United Kingdom', The Geneva Papers on Risk and Insurance - Issues and Practice 28: 612-624.

Taylor, P.E. and Walker, A. (1994) 'The ageing workforce: employers' attitudes towards older people', Work, Employment \& Society 8: 569-591.

The European Union Labour Force Survey (1995).

\section{About the Author}

Per H. Jensen, Ph.D., is associate professor in Comparative Welfare Studies, Centre for Comparative Welfare Studies, Aalborg University and Director of the Danish National Research School on Welfare State and Diversity. 